\title{
Dissonance in Global Financial LaW
}

\section{DALIT FLAISZHAKER*}

This article explores whether the post-GFC global financial architecture is likely to provide efficient regulation capable of preventing a future crisis from occurring. The article starts with a brief overview of the emergence in the 1970s of global financial architecture. A thorough descriptive analysis of the post-crisis architecture follows, raising serious doubts regarding the current architecture's ability to accomplish its goal. This analysis is performed in two stages, taking first an outsider's perspective on the changes the architecture underwent after the crisis and moving then to the inside - the structure and contents of the architecture. Using macro-prudential methodological tools, the establishment of the Financial Stability Board is reviewed, along with three cutting edge regulations: the Basel III framework for banking, the IOSCO's recommendation for money market funds, and the $F S B$ 's recommendations regarding repurchase agreements. Pointing out the architecture's perceived failure to provide stability due to severe regulatory arbitrage, the article then widens the lens to explore the implications of the above regulation. The article suggests that the current architecture encourages 'financialisation' and pushes the financial system and the real economy further apart. Consequently, the article raises normative concerns regarding the legal foundations of the global financial architecture, and its legitimacy.

\section{INTRODUCTION}

Following the global financial crisis beginning in 2007-2008 ('GFC'), financial regulation seems to be at the centre of current lawmaking in the economic sphere. As many commentators hold regulation (or lack thereof) responsible, if not for the occurrence of the crisis then at the very least for not mitigating it, this regulation has become a target of widespread interest. Regulators

\footnotetext{
* LLM (summa cum laude), Tel Aviv University; PhD candidate at the Zvi Meitar Center for Advanced Legal Studies, Tel Aviv University; junior researcher with the Financial Division of the Bank of Israel Research Department. As this article is partially based on my LLM thesis, I would like to thank Prof Roy Kreitner, my thesis advisor, for his endless patience and wisdom and Prof Eyal Benvenisti for his helpful comments. I acknowledge financial support from the Meitar Center during the writing of my LLM thesis. The views expressed in this article are my own.
} 
worldwide, both nationally and internationally, have produced reports investigating the crisis and have promoted new reforms intended to prevent the next one. Academic writing has not lagged behind, as thorough discussions have been devoted to solving the trillion-dollar problem: how to create a stable financial system, implementing the lessons the GFC has taught us.

This article is different. It will not focus on the stability issue per se. Although stability will be investigated in the article, an understanding of it will be used as a necessary platform on which to build the article's main argument. It will be argued that to crown stability as the goal of global financial regulation is to obscure other critical implications that this regulation has for the real economy. ${ }^{1}$ It will be argued that the emphasis given to stability supports a separation of the financial system from the real economy, and that the expected consequences of the current global financial regulation raise serious doubts not only regarding its effectiveness, but also regarding its legitimacy.

Before we can grasp the findings of the article, we need to consider the current financial architecture.

Part II of this article is a prologue, taking a quick journey back in time to the early 1970s and covering the period leading up to the GFC. The shift from the Bretton Woods monetary regime to a regime of floating exchange rates with free capital movements created an urgent need for global regulatory cooperation. This Part will briefly describe the emergence of global regulatory bodies, and their regulatory soft law products. The global financial architecture holds the potential to level the global playing field to an even plane of safety and competitiveness, which will resist a regulatory race to the bottom, for the benefit of all states.

The GFC marked a turning point for the global financial architecture. Part III will briefly describe the crisis, focusing on its most valuable lesson: the need to create regulation using a macro-prudential approach. Regulating each sector or institution separately (micro-prudential regulation) is insufficient to address the systemic character of financial risk. The implementation of macro-prudential policy in the global architecture after the crisis resulted in three major changes, described in the fourth Part: the founding of a new 'super' regulatory body the Financial Stability Board; the creation of massive new regulation, intended to cover financial institutions and activities not regulated prior to the crisis and to tighten supervision in the already supervised fields; and the efforts made to

\footnotetext{
${ }^{1}$ The 'real economy' is composed of the total output of a given economy. It includes, for example, industrials, consumer goods, and utilities. Hence, it is connected to employment rates. The term is often used also to differentiate these factors from the financial system.
} 
enhance the coercive power of the regulation in order to achieve improved (national) obedience to it. From an outsider's perspective, the post-crisis architecture appears stronger and more coherent than before.

The fifth Part closely examines the above changes. A two-stage legal critical analysis is performed. First, the analysis examines the structural change, with the FSB now positioned over the pre-existing three specialised sectorial authorities. Re-depositing the creation of prudential regulation with the same bodies that had proved themselves unable to mitigate the GFC may be problematic. The structural change may arguably be considered an improvement compared to the previous architecture, yet it is far from being adequate.

Second, the article inspects the change in the contents of global regulation. Three pieces of regulation in the banking field ('Basel III'), the money market funds ('MMFs') field, and the repurchase agreement ('repo') market are compared. These pieces of regulation are at the cutting-edge of the current architecture's work. They offer a good case for comparison as the crisis exposed the vulnerability of the MMFs and repos to the known event of a 'bank run'. Comparing these solutions offered to the similar problem demonstrates that, whereas banks are regulated in a stringent manner likely to be effective, MMFs and repos are not. This creates a regulatory arbitrage, which is likely to lead credit to be accumulated in the less-constrained shadow banking sector. This concentration of credit constitutes systemic risk, as from there it can spread to other parts of the financial system. Despite the unified appearance of today's regulatory regimes, fragmentation is still present in the current architecture. Failing to provide for a coherent treatment and coverage, the new global regulation is likely to be ineffective in preventing the next crisis.

The sixth Part then turns to observe the expected consequences of the regulatory arbitrage, this time not focusing solely on the effectiveness of the regulation. Explaining how the phenomenon of 'financialisation' causes estrangement of the financial system from the real economy, I argue that the new global regulation is likely to push the two further apart. The conclusion is that, while focusing on the goal of stability, the global architecture could be sabotaging the 'meta-goal' of the financial system - promoting the real economy.

This conclusion raises questions about the legitimacy of the new global regulation. The severe repercussions of financial regulation as described, along with the fact that regulation occurs at the global level, point to a unique democratic deficit. The concluding Part raises this currently unresolved issue, and opens a path for future research on how to make things better. 


\section{What Do We Talk about When We Talk about 'GLOBAL FINANCIAL LAW'?}

Nowadays much of financial regulation is created in the global sphere, and injected into national law. This Part describes, in a nutshell, the emergence of global financial law in the early 1970s and its development into its current form. This historic overview will provide the framework needed for the subsequent discussion, as it will explain the justification for creating financial law at the global level, and will identify the leading bodies that create it and how they function.

The 1970s were a turbulent decade as far as the international economic atmosphere was concerned. The major change was the collapse of the Bretton Woods international monetary regime, which had lasted from the end of World War II. $^{2}$ The Bretton Woods regime was based on fixed exchange rates, operated by pegging currencies to the US dollar and pegging the dollar to the gold rate, and controls on capital movements between states. These two features enabled each state to participate in the international regime, while preserving the ability to create monetary policy independently. It is common to refer to the US's 'closing of the gold window' (that is, the decision to cancel the pegging of the dollar exchange rate to gold), in the summer of 1971, as the point of the Bretton Woods regime's collapse. Gradually, after the collapse, most of the industrial countries which likewise cancelled the fixed exchange rate mechanisms had also to cancel the limitations on international capital movements in an effort to maintain their ability to pursue independent monetary policy. States found that it was impossible to maintain at the same time floating exchange rates, limitations on capital movement and independent monetary implementation - a predicament known as the 'open-economy trilemma' or the 'impossible trinity'. ${ }^{3}$ These developments resulted in a new international monetary regime, based on floating exchange rates and free capital flow, which has existed till the present.

Lifting the capital barriers was a major factor in facilitating the integration between national financial systems, and ultimately an interwoven global financial system. ${ }^{4}$ Other factors encouraging this process included:

${ }^{2}$ For a detailed examination of the 'Bretton Woods' era, see Barry J Eichengreen, Global Imbalances and the Lessons of Bretton Woods (MIT Press, 2007).

${ }^{3}$ For a description of the 'impossible trinity' see J Lawrence Broz and Jeffry A Frieden, 'The Political Economy of International Monetary Relations' (2001) 4 Annual Review of Political Science 317, 322.

${ }^{4}$ Before this process of globalisation occurred, the focus of financial activity was nation based, despite the existence of some limited connections between states: Susan Strange, Authority and Markets: Susan Strange's Writings on International Political Economy (Roger Tooze and 
technological development (such as the development of computers and advanced communications) which made it possible to execute international financial transactions quickly and efficiently; increased international trade, which led to a growing need for credit, provided by the inter-state financial system; the desire to spread investments due to fluctuations in interest rates during those years; and various states' policies supporting the growth of the financial sector and its integration among countries (for example, by the easing of regulatory limitations). ${ }^{5}$ These were policies that were partially based on the 'Washington consensus', 6 and aimed to liberalise economic activity and encourage free markets. From this point onwards, the new monetary regime combined with the factors just mentioned to generate a 'financial globalisation', resulting in a globalised financial system.

A prominent example of this process was the development of the Eurodollars market, which included banking activity performed in US dollars outside the territory of the US (mostly in London). This market was composed of high sum transactions amounting in 1988 to USD 4 trillion. ${ }^{7}$ One of the reasons for the development of this market was banks' ability to avoid US regulatory limits and reserve requirements when operating outside the US. A second example of this financial globalisation was the transformation of the banking system from a system based in a home state, to a system having many branches in different states. The creation of a very active foreign exchange market was a third example. ${ }^{8}$

The creation of a new global financial system, in addition to the national ones, answered the pressing needs of that time, and had various potential advantages. The principal advantage attributed to the global financial system was its ability to support global growth, which would be nearly impossible to achieve without it. However, trying to solve some problems may create new and unexpected

\footnotetext{
Christopher May eds, 2002) 72, 88-90. See also Dani Rodrik, One Economics, Many Recipes: Globalization, Institutions, and Economic Growth (Princeton University Press, 2007) ch 7. For previous waves of globalisation see Roy Kreitner, 'The Jurisprudence of Global Money' (2010) 11 Theoretical Inquiries in Law 177.

${ }^{5}$ Eric Helleiner, States and the Reemergence of Global Finance: From Bretton Woods to the 1990s (Cornell University Press, 1994) 5-12.

${ }^{6}$ The 'Washington Consensus' is a set of policy reforms, including, for example, the deregulation of financial institutions, trade liberalisation and so forth.

${ }^{7}$ George H Windecker, 'The Eurodollar Deposit Market: Strategies for Regulation' (1993) 9(1) American University International Law Review 357, 357-8.

${ }^{8}$ The worth of assets of American banks managed in branches outside the US rose in those years from USD 4 billion to USD 230 billion. The daily foreign exchange is estimated as having been USD4 trillion in 2010. Pierre-Hugues Verdier, 'The Political Economy of International Financial Regulation' (2013) 88(4) Indiana Law Journal 1405, 1414-15.
} 
ones. The global financial system, as it turned out, introduced a new challenge for national regulators.

Traditionally, the primary goal for financial regulators was to maintain the stability of their national financial system. Stability is important for financial regulators since the financial system is a crucial link in the chain of economic activity, and a crisis in the financial system can develop into a much wider economic crisis. ${ }^{9}$ At the same time, too many regulatory restrictions on the activity of the financial system can lead to too much stability, which may impede economic activity by not supplying all the credit needed to support economic growth. Balancing the degree of stability of the financial system at optimal levels requires a dynamic responsive regulatory approach; the regulator needs to be attuned to the needs of the economy so as to ease the restraints in the right measure and at the right time.

The regulatory challenge became harder to manage as the financial system grew global. When the centre of the financial system was national, regulators had better control over the financial institutions in their territory. Linking the national financial systems to a global system created a double-edged sword. On the one hand, due to globalisation, capital and financial institutions could move (or threaten to move) to countries with more lenient regulatory regimes. The problem was that the desire of countries to attract capital and to encourage local financial institutions to compete with foreign ones, or to appeal to foreign institutions to establish themselves in those countries, might lead to a regulatory race to the bottom. The expected outcome of such a race could be damage to the stability of the financial system. Simultaneously, due to the close ties between financial systems, each system had become much more prone to a crisis started in other countries. In that sense, a country with more lenient rules could pose a danger not only to itself but also to other countries, since crises can move easily and quickly from one country to another. Combining these two phenomena - the regulatory race to the bottom and contagion - led to the understanding that regulating the financial system only at the state level was no longer sufficient, and that global cooperation was needed in order to create effective financial regulation. ${ }^{10}$ Setting standards at the global level that were both beneficial and uniform across countries could reduce the incentive for a

\footnotetext{
${ }^{9}$ Frederic S Mishkin, The Economics of Money, Banking and Financial Markets (Pearson, $9^{\text {th }}$ ed, 2009).

${ }^{10}$ Adam Feibelman, 'Law in the Global Order: The IMF and Financial Regulation' (2017) 49(3) New York University Journal of International Law and Politics 687, 693-702.
} 
regulatory race to the bottom and improve the international prudential level, thus minimising the risk of contagion, for the benefit of all countries. ${ }^{11}$

Indeed, in 1974 the G-10 leaders established the Basel Committee on Banking Supervision (the 'Committee'). The Committee aimed at creating regulatory standards for international banks, and was initially composed of representatives of central banks from 11 countries, broadening its membership to 28 countries today. ${ }^{12}$ The founding of the Committee represented global regulatory cooperation in response to the concerns raised following the collapses of the German Herstatt Bank, the American Franklin National Bank, and later on of the Italian Banco Ambrosiano, ${ }^{13}$ which spread panic in capital markets and led to a halt in international financial activity. ${ }^{14}$ A year after its foundation, the Committee published its Report on the Supervision of Banks' Foreign Establishments (the Concordat), ${ }^{15}$ which set rules for central bank bailouts of failing banks, differentiating between the bank's home state, and states in which that bank had opened branches.

The Committee's main achievement was the Basel Capital Accord, which in its first version of 1988 set the ratio of capital to risk-weighted assets for banks at $8 \%{ }^{16}$ The capital ratio is a good example of the two phenomena described above, since a higher ratio enhances the resilience of banks, and lowers the chances of insolvency. On the other hand, a higher ratio entails costs for banks, which may lead to a regulatory race to the bottom in the desire to improve competitiveness. ${ }^{17}$ During the following years, the Basel Accord underwent several changes known as 'Basel II', 'Basel 2.5', and recently 'Basel III' -

${ }^{11}$ David Andrew Singer, Regulating Capital: Setting Standards for the International Financial System (Cornell University Press, 2007) 25-32, 36-66. One can also regard this transfer as part of a more general movement towards creating regulation at the global level: see Eyal Benvenisti and George W Downs, 'Court Cooperation, Executive Accountability and Global Governance' (2009) 41(4) New York University Journal of International Law and Politics 931, 931-32.

12 The Basel Committee is located at the Bank for International Settlements ('BIS'). See BIS (Web Page) <https://www.bis.org/bcbs/about/overview.htm?m=3\%7C14\%7C573\%7C77>.

${ }^{13}$ Ulrich Hess, 'The Banco Ambrosiano Collapse and the Luxury of National Lenders of Last Resort with International Responsibilities' (1990) 22(2) New York University Journal of International Law and Politics 181, 188-191.

${ }^{14}$ Verdier (n 8) 1416-17.

${ }^{15}$ BIS, Report on the Supervision of Banks' Foreign Establishments - Concordat (28 September $1975)<$ https://www.bis.org/publ/bcbs00a.htm>.

16 The Accord was intended only for international banks within the countries of the Committee members. However, it was adopted in more than 100 countries, and applied to all banks. It was therefore considered a success. Singer (n 11) 61-2.

17 The capital ratio issue can be viewed as a market failure, requiring global regulatory intervention. 
which will be discussed below — in order to adjust the regulation to changes in the financial market.

Subsequent to the founding of the Committee, a few attempts were made to form a regulatory body for the securities sector, resulting in the establishment of the Board of the International Organization of Securities Commissions ('IOSCO') in 1983. Over the years, IOSCO enlarged its membership from 48 countries to almost all countries today. Initially, IOSCO focused on cooperation between states mainly in regard to fraud in the stock market. Gradually, IOSCO turned its attention to problems resulting from the ongoing globalisation of the capital and stock markets. In the 1980s and 1990s IOSCO initiated several reports ${ }^{18}$ the findings of which were not able to achieve wide implementation among states. In 2002 IOSCO created a Memorandum of Mutual Understandings regarding cooperation and information sharing between national securities supervisors, signed by most of its member states. ${ }^{19}$

The third step taken in the formation of the pre-crisis global financial architecture was the establishment of the International Association of Insurance Supervisors ('IAIS') in $1994 .{ }^{20}$ IAIS aims to handle the challenges arising from the globalisation of the insurance field, particularly the reinsurance field. IAIS includes representatives from regulatory and supervisory authorities of nearly 140 states, amounting to $97 \%$ of the world insurance market, in addition to observers from international insurance companies. In 2003 IAIS published standards for effective supervision of insurance companies. ${ }^{21}$

To summarise, financial regulation was created at the global level from the 1970s onwards, by specialised bureaucratic bodies, each within its own field of expertise, divided between the three traditional sectors of finance: banking, securities, and insurance. The regulation was created in the form of soft law, with different enforcement success. ${ }^{22}$ We can identify the three bureaucratic bodies - the Committee, IOSCO and IAIS - as key components of the global regulatory financial architecture, given their common objective of creating

\footnotetext{
${ }^{18}$ Singer (n 11) 72-6.

${ }^{19}$ See OICU-IOSCO (Web Page) $<$ https://www.iosco.org/about/?subsection=about_iosco $>$. For the globalisation of capital markets, see Singer (n 11) 73-6 and 92-5.

${ }^{20}$ In this article, the scope of 'financial regulation' relates to the three traditional sectors of banking, securities and insurance, and does not include other topics, such as accounting or money laundering, that could be included in a wider definition of 'financial'.

${ }^{21}$ See IAIS (Web Page) <https://www.iaisweb.org/page/about-the-iais>.

${ }^{22}$ Chris Brummer, Soft Law and the Global Financial System: Rulemaking in the $21^{\text {st }}$ Century (Cambridge University Press, 2012) 60-7, 117. See there for an explanation why the dichotomy of hard/soft law is not accurate, as will be explained in Part IV.
} 
global stability, and their common practice of using soft law mechanisms, and notwithstanding their differences.

And then came the big bang.

\section{The Recent Financial Crisis and Its Lessons}

The question of what caused the severest financial crisis since the Great Depression can be answered in several ways. A number of factors have been identified as being responsible for the GFC, such as the deregulation of financial markets in the years predating the crisis, ${ }^{23}$ and the more innovative and complex financial products appearing in those years. It is also possible that a number of factors combined contributed to its occurrence, in a kind of a 'perfect storm'. ${ }^{24}$

However, it is common to regard the immediate cause of the crisis as the bursting of the US housing bubble. Low interest rates since the 1990s, along with the flow of foreign capital into the US, increased the flood of capital into the real estate market. This capital in search of borrowers increased the incidence of what were called 'sub-prime' housing loans. Sub-prime loans are riskier than normal loans due to the borrowers' questionable future solvency; these loans are considered less than prime. ${ }^{25}$ Recipients of these loans were usually unable to receive credit in the mainstream banking system, hence receiving it through alternative financing channels.

What made matters even worse was that these loans underwent a process of securitisation. Securitisation consolidated loans with different risk levels, in ways that became increasingly sophisticated, into 'Mortgage Backed Securities' ('MBSs'). MBSs were considered safe, due to the risk diversification they supposedly enabled, and were marketed by distinguished investment banks. MBSs were bought by solid investors among which were banks. This led borrowers who were initially rejected by the banking system indirectly back into it. At the same time, innovative financial instruments such

\footnotetext{
${ }^{23}$ The fact that there was more activity at the global level, as just described, does not contradict the general view of 'deregulation'.

${ }^{24}$ Adam J Levitin, 'The Politics of Financial Regulation and the Regulation of Financial Politics: A Review Essay' (2014) 127(7) Harvard Law Review 1991, 2039-41. See also Brummer (n 22) 11-13. In what follows I will give a simplified version of the events.

${ }^{25}$ See Atif Mian and Amir Sufi, House of Debt: How They (and You) Caused the Great Recession, and How We Can Prevent It from Happening Again (University of Chicago Press, 2014) 96-105.
} 
as 'Credit Default Swaps' ('CDSs' $)^{26}$ were created with the purpose of protecting the MBSs against the insolvency of borrowers, and thus enhanced the safety of MBSs. The financial alchemy transformed great risks joined together into a seemingly safe investment product.

In 2006-2007 interest rates began to rise. As a result, many borrowers who held sub-prime loans experienced difficulties in making their mortgage payments. Financial companies that sold CDSs were forced to answer growing margin calls in addition to paying compensation and began to suffer heavy losses themselves. In 2007 a relatively small financial crisis occurred, which was considered at that time one that the supervisory system was able to block. However, in September 2008 one of the biggest investment banks in the US Lehman Brothers - collapsed. Due to the ensuing overall panic, its collapse led to a chain of problems not only in many of the financial institutions - banks and non-banks - connected to Lehman, but also in ones that had minor connections to it, due to the overall panic. After the collapse, it became evident that even established financial institutions, such as the American International Group (AIG), were no longer able to meet their obligations. ${ }^{27}$ This led to a general loss of confidence in the financial market, and even financial institutions that could lend to other institutions refused to do so for fear of nonrepayment, so that a general credit crunch swept the US financial market. From there, the crisis spread to other countries such as the UK and Germany, leading to a European economic crisis.

As described above, financial regulation created at the global level prior to the crisis was divided between the three traditional sectors of banking, securities and insurance. In each sector, the main focus of the regulation was on ensuring the stability of each individual financial institution. For example, the banking regulation was designed by the Committee in the regulatory framework of the Basel Accord. The Basel Accord determined that the capital ratio that each bank needed to hold must be sufficient to enable the bank to absorb losses. The underlying assumption was that, if the regulation would be able to ensure the stability of each individual bank, the stability of the banking system would consequently be ensured. That was because the banking system is composed of the aggregate of all the individual banks. Similarly, the premise behind the divided sectorial supervision was that ensuring the stability of each financial

\footnotetext{
${ }^{26} \mathrm{CDSs}$ are financial derivatives, which enable one party to the contract to buy protection against the risk of credit default. In the event of such default, the protection seller pays the buyer the amount of money that buyer would have received from the (defaulted) third party.

27 'The Financial Crisis Inquiry Report', Financial Crisis Inquiry Commission (January 2011) $<$ https://fcic.law.stanford.edu/report/>.
} 
sector separately would ensure the stability of the financial system as a whole, the whole being the sum of its parts.

The crisis destroyed these assumptions. It became clear that addressing the stability of each financial institution/sector, following micro-prudential policy, is not sufficient to guarantee the stability of the system. The crisis demonstrated the need to supplement micro policy with macro-prudential policy. Macroprudential policy focuses on systemic stability, and is essential for two primary reasons. ${ }^{28}$ First, micro-supervision does not address cross-institutional and cross-sectorial linkages and interactions across the financial system. Many financial institutions are connected to other institutions from the same sector and from other sectors, creating a web of interdependence. ${ }^{29}$ When those connections become channels for transferring difficulties on a large scale, they require close attention from regulators. Second, the pace at which new financial products are developed requires broad and dynamic supervision of all financial activities and the institutions performing them. Concentrating only on the three traditional sectors ignores new financial activity happening outside the formal system, activity which has potential effects on the financial system (for example, the non-bank sector).

Macro-prudential policy, the cardinal regulatory solution derived from the crisis, is intended to enhance the stability of the financial system by addressing its systemic potential for risk. ${ }^{30}$ To achieve this goal, macro-prudential policy utilises a few sets of tools, among which the two relevant for our upcoming discussion are: a structural tool - creating coordination and cooperation between the different bodies supervising the financial system; and a contents tool - developing new regulatory means to supervise the financial system as a whole.

While Part II of this article described the pre-crisis architecture of the global financial law, and Part III has provided us with an understanding of the primary

\footnotetext{
${ }^{28}$ Robert Hockett, 'The Macroprudential Turn: From Institutional "Safety and Soundness" to "Systemic Stability" in Financial Supervision' (2015) 9(2) Virginia Law and Business Review 201, 206-14. As Hockett describes, the macro-prudential policy predated the recent crisis, yet received a great boost after it: at 204 .

${ }^{29}$ A very simplified example could be a bank that borrows money from a different bank, lends it to an investment fund (profiting on the interest margin), and buys insurance against default from an insurance company. If the investment fund fails to pay back the loan, the second bank will activate its insurance policy, and may experience difficulties returning the money it has itself borrowed.

${ }^{30}$ Gabriele Galati and Richhild Moessner, 'Macroprudential Policy: A Literature Review' (2013) 27(5) Journal of Economic Surveys 846, 847-8.
} 
insights of the recent crisis, the fourth Part will explore how these lessons were manifested in the post-crisis global architecture.

\section{THE POST-CRISIS ARCHITECTURE FROM AN OUTSIDER's PERSPECTIVE}

Three major changes were made to the regulatory financial architecture after the crisis, as part of the implementation of the newly introduced macroprudential policy. The changes will be shortly mentioned at first, and elaborated separately afterwards. The first change was a structural change: the establishment of a new supervisory authority. The second was a change in contents, creating new regulations. The third change concerned new means taken to strengthen the enforcement capabilities of the regulatory bodies.

The structural change took place in 2009, when the G-20 announced the establishment of the Financial Stability Board ('FSB'). ${ }^{31}$ The members of the FSB are the G-20 countries (usually represented by their central bank and ministry of finance), in addition to global and international bodies, such as the Committee, and the International Monetary Fund ('IMF'). The FSB was founded on an existing platform - the Financial Stability Forum ('FSF').

The FSB's chief objective is to supervise the work of the global standard-setting bodies. $^{32}$ To achieve this goal, the FSB's mandate includes the task of monitoring the development of macro-prudential policy, based on vulnerabilities identified in the global financial system. The FSB is to review the coordination between the regulatory authorities, and to make sure they collaborate with each other. The FSB is also charged with the task of promoting member jurisdictions' implementation of agreed commitments, standards and policy recommendations through monitoring, peer review, and disclosure.

During the establishment of the FSB, a choice had to be made regarding the institutional design of the global financial architecture. There are two acceptable models for financial regulatory design: ${ }^{\text {the }}$ single regulator model and

31 The G-20 is an economic forum of 20 leading countries. See G-20, 'Declaration on Strengthening the Financial System', G-20 Information Centre (2 April 2009) $<$ http://www.g20.utoronto.ca/2009/2009ifi.html>; Eric Helleiner, 'What Role for the New Financial Stability Board? The Politics of International Standards after the Crisis' (2010) 1(3) Global Policy 282. For global financial governance see also Giulio Napolitano, 'The "Puzzle" of Global Governance after the Financial Crisis' in Sabino Cassese et al, Global Administrative Law: An Italian Perspective (Robert Schumann Centre for Advanced Studies, 2012) 31, 32-4.

${ }^{32}$ Financial Stability Board, 'Charter of the Financial Stability Board' (June 2012) arts 1-2 $<$ http://www.fsb.org/wp-content/uploads/FSB-Charter-with-revised-Annex-FINAL.pdf $>$. 
multiple specialised authorities. ${ }^{33}$ The single regulator model, as implied by its name, consists of one authority that is responsible for covering all financial regulation. The second model is composed of several authorities. These regulatory authorities can be divided up in a sectorial manner, so that each of the three traditional sectors has its own authority. That was the model of the global architecture prior to the crisis. Responsibility can otherwise be divided according to the different objectives of the authorities. For example, one authority can be responsible for financial stability and another for consumer protection, in a sub-model known as the 'twin peaks' model.

Picturing an axis, with the single regulator model on one side, and the multiple regulators on the other (regardless of their exact division), we can locate the FSB more or less at its midpoint. The FSB primarily supervises the other standard-setting bodies and does not create regulation itself; hence it is not a single regulator model. Yet it is not a pure multiple regulator model either, as there exists another supervising regulator over the standard setting bodies. The current architecture can be regarded as a 'consolidated' model, which will enable more coordination than the pre-existing one.

In parallel with the structural change, a massive expansion of the regulation produced by the global regulatory bodies occurred. The need to supplement the pre-crisis micro-prudential regulation with macro-prudential policy validates this expansion. The regulation expanded to include new financial institutions and new activities, which were not covered by former regulation. The regulation also expanded in regard to previously regulated institutions, which became subject to more stringent demands.

The new regulation has four focal points. The first is 'Basel III: A Global Regulatory Framework for More Resilient Banks'. Basel III includes significant updates to the capital ratio set by its predecessor (Basel 2.5) and

\footnotetext{
${ }^{33}$ For a discussion of these models see Eric J Pan, 'Structural Reform of Financial Regulation' (2011) 19(3) Transnational Law and Contemporary Problems 796, 816-24. Choosing the appropriate model for a national regulator involves choosing between different pros and cons of each model, such as more coherent regulation in the single regulator versus more separation of powers in the multiple authorities. See also Eric J Pan, 'Challenge of International Cooperation and Institutional Design in Financial Supervision: Beyond Transgovernmental Networks' (2010) 11(1) Chicago Journal of International Law 243. For the importance of new regulatory design see Olufunmilayo B Arewa, 'Financial Markets and Networks Implications for Financial Market Regulation' (2009) 78 University of Cincinnati Law Review 613, 626.
} 
adds a counter-cyclical capital buffer. Basel III also includes new demands on banks, such as the liquidity coverage ratio and the leverage ratio. ${ }^{34}$

The second focal point is the approach towards the shadow banking sector, which is defined as 'credit intermediation involving entities and activities outside the regular banking system'. ${ }^{35}$ The need to regulate this sector was exposed during the GFC, which started with the collapse of Lehman Brothers, an investment bank (hence not a licensed depository institution), and intensified in the face of the connections between this sector and the traditional banking sector. Relevant parts of the Basel III framework and of the shadow banking regulation will be further investigated in the next Part.

The third focal point is regulation of 'Systemically Important Financial Institutions' ('SIFIs') which, due to their size and connections, have a greater potential to affect the financial markets than smaller institutions do. This kind of institution requires stricter treatment, which includes the enlargement of their loss-absorbing capacities, their orderly liquidation, and closer supervision at the national level. ${ }^{36}$

The fourth focal point is the regulation of derivatives. 'Over the counter' ('OTC') derivatives are contracts between two financial sides, whereby one side takes on a financial obligation derived from the future position of a certain asset. As those contracts are bilateral, and tailored for the individual needs of each deal, most of them have in the past not been supervised. Yet derivatives have potentially immense impacts on the financial market, as the global

\footnotetext{
${ }^{34}$ Basel Committee on Banking Supervision, 'Basel III: A Global Regulatory Framework for More Resilient Banks and Banking Systems', Bank for International Settlements (December 2010, revised June 2011) <http://www.bis.org/publ/bcbs189.pdf>; Basel Committee on Banking Supervision, 'Basel III: The Liquidity Coverage Ratio and Liquidity Risk.Monitoring Tools', Bank for International Settlements (January 2013) <http://www.bis.org/publ/ bcbs238.pdf $>$ ('Liquidity coverage ratio') and Basel Committee on Banking Supervision, 'Core Principles for Effective Banking Supervision', Bank for International Settlements (September 2012) <http://www.bis.org/publ/bcbs230.pdf $>$. Basel 3 was finalised in December 2017: Basel Committee on Banking Supervision, 'Basel III: Finalising Post-Crisis Reforms', Bank for International Settlements (December 2017) <https://www.bis.org/bcbs/publ/d424.pdf>.

${ }^{35}$ FSB's definition; see 'Shadow Banking: Scoping the Issues: A Background Note of the Financial Stability Board', Financial Stability Board (11 April 2011) <http://www.fsb. org/2011/04/shadow-banking-scoping-the-issues/>. See also 'Strengthening Oversight and Regulation of Shadow Banking: An Overview of Policy Recommendations', Financial Stability Board (29 August 2013) 2 <http://www.financialstabilityboard.org/publications/r_130 829a.pdf $>$.

${ }^{36}$ FSB in consultation with the IMF, 'Intensity and Effectiveness of SIFI Supervision: Recommendations for Enhanced Supervision', Financial Stability Board (2 November 2010) $<\mathrm{http}$ ://www.financialstabilityboard.org/publications/r_101101.pdf $>$.
} 
derivatives market is valued at over USD 500 trillion (the notional value of the OTC Market) and involves many financial institutions. ${ }^{37}$ Efforts are being made, for example through pushing OTC derivatives into formal exchange, and thus bringing derivatives into the regulatory net, to subject them to supervision.

On top of these structural and contents changes, the third change involves new means taken to strengthen global regulation's enforcement power. This is not a 'change' in the simple meaning of the word, since enhancing the enforcement of regulation has been an important goal of the architecture since its emergence. ${ }^{38}$ The financial playing field cannot be levelled without all countries accepting global regulation. Global financial regulation is classified as soft law, in the form of standards and recommendations, which, in contrast to hard international law, lacks official enforcement mechanisms.

Hence, a problem of cooperation may arise, as a single state may have the incentive to individually defect from the cooperation. ${ }^{39}$ Such a state can then enjoy the benefits that global regulation supplies - the benefits of global stability deriving from all other states obeying the rules — while taking advantage of its own non-restricted status. ${ }^{40}$ To cope with this problem, global financial regulation developed enforcement measures, even prior to the crisis. These included the use of market discipline, as the market punishes states (for example, by imposing higher interest rates on them) that do not apply global standards. They also included institutional backup from formal international bodies, for example through the IMF making loans conditional on the implementation of global financial standards. ${ }^{41}$ These enforcement measures are unique to global financial regulation and contribute to the 'hardening' of financial soft law. Thus, financial regulation can retain the benefits of soft law

${ }^{37}$ As of December 2009: 'Implementing OTC Derivatives Market Reform', Financial Stability Board (October 2010) Annex 2 <http:/www.financialstabilityboard.org/publications/ r_101025.pdf>. Gross market values were around USD 13 trillion in 2017: 'Statistical Release: OTC Derivatives Statistics at End June 2017', Bank for International Settlements (2 November 2017) $2<$ https://www.bis.org/publ/otc_hy1711.pdf $>$.

${ }^{38}$ For the need of global regulation for domestic implementation see Benedict Kingsbury et al, 'The Emergence of Global Administrative Law' (2005) 68(3/4) Law and Contemporary Problems 15, 44-5.

${ }^{39}$ For a description of financial regulation as a coordination problem see Chris Brummer, 'How International Financial Law Works (and How It Doesn't)' (2011) 99 Georgetown Law Journal 257.

40 See John C Coffee, 'Extraterritorial Financial Regulation: Why E.T. Can't Come Home' (2014) 99(6) Cornell Law Review 1259, 1269-71, claiming that financial stability is a 'public good', exposed to the 'tragedy of the commons'.

${ }^{41}$ Another means is the shaming of a rogue state. See Brummer (n 24) 50-7 and 170-5. See also David Zaring, 'Finding Legal Principle in Global Financial Regulation' (2012) 52(3) Virginia Journal of International Law 683, 685-6. 
- in particular its capacity to be created and changed fast, to be flexible and to be created by specialists (as opposed to political bodies) — but with some of the benefits of formal international law.

Nonetheless, after the GFC efforts were made to enhance the financial regulatory architecture's enforcement mechanisms even further. Almost every regulation created by the global bodies after the crisis is accompanied by a supervisory methodology which should be followed. Each regulation is followed by assessment reports, evaluating on a consistent basis the compliance of countries with the rules. In addition, the FSB has created a system of regular peer review of member states. ${ }^{42}$ The implementation of the Basel III framework provides a good example of these procedures, as it is being reviewed in no less than four different ways: through the Regulatory Consistency Assessment Programme whose report is published by the Committee every six months (starting in 2012), evaluating the progress of every member country in implementing the rules; through a thematic report, which extends the findings of the other reports; through the IMF's reports, which also review the implementation of parts of Basel $\mathrm{III} ;{ }^{43}$ and finally, through a review by the Bank for International Settlements ('BIS') on the implementation of Basel rules in non-member states. ${ }^{44}$

These three changes lead to the conclusion that the global financial architecture after the crisis seems more coherent, united, and stronger than previously. The changes made to the architecture - structural, contents, and enforcement changes - are encouraging. However, given the past failures of the global architecture to prevent several financial crises, a realistic examination is in order before one can accept that 'this time it is different'. This realistic examination calls for a deeper look into these changes.

42 As described by the FSB: 'Peer Reviews', Financial Stability Board (Web Page) $<$ https://www.fsb.org/work-of-the-fsb/implementation-monitoring/peer_reviews/>.

${ }^{43}$ See the IMF's financial sector assessment program: 'Financial Sector Assessment Program', International Monetary Fund (Fact Sheet, 8 March 2018) <https://www.imf.org/en/ About/Factsheets/Sheets/2016/08/01/16/14/Financial-Sector-Assessment-Program>.

${ }^{44}$ See the Committee's web site, Basel Committee on Banking Supervision (Web Page) $<$ http://www.bis.org/bcbs/implementation.htm>. See also Basel Committee on Banking Supervision, 'Basel III Regulatory Consistency Assessment Programme (RCAP)' (October 2013) $1-3<$ http://www.bis.org/publ/bcbs264.pdf>. 


\section{THE POST-CrISIS ARCHITECTURE FROM AN INSIDER'S Perspective}

\section{A Fragmented Structure}

While trying to appreciate the perceived effectiveness of the consolidated model, its past experiments in financial regulation may provide valuable insights. In the spirit of the statement that "those who cannot remember the past are condemned to repeat it', two such experiments will be examined: the Financial Stability Forum ('FSF') and the Financial Services Authority ('FSA'). But first, a few more words on the FSB role are in order.

As mentioned above, the FSB mostly does not on its own create the regulatory standards. For example, the FSB divided the formulation of regulation on shadow banking among three regulatory bodies, based on their expertise. The Committee was made responsible for dealing with the connections between the banking system and the shadow banking sector; IOSCO was made responsible for regulating MMFs, being investment vehicles that are supervised by securities regulation; and the FSB itself was responsible for creating the regulatory framework for the shadow banking sector and for regulating every institution or activity that holds the potential for risk and that is not a bank or MMF. ${ }^{45}$ In a similar manner, the regulation of SIFIs was divided between four regulatory bodies. The Committee formulates regulation for globally important banks, IAIS formulates regulation for SIFIs that are insurance companies, IOSCO for SIFIs that are neither banks nor insurers, and the FSB is in charge of creating the general framework to be reported to the G-20. ${ }^{46}$

More generally, and in accordance with its primary supervising role, ${ }^{47}$ the FSB joins together the regulations created by each of the standards-setting bodies to form a 'compendium of standards', which currently contains twelve standards

\footnotetext{
45 'Policy Recommendations for Money Market Funds: Final Report' ('IOSCO Policy Recommendations'), IOSCO (October 2012) 1-5 <https:/www.immfa.org/assets/files/ publications $/$ IOSCO $\% 20$ Policy $\% 20$ Recommendations $\% 20$ for $\% 20$ Money $\% 20$ Market $\% 20$ Fun ds\%20-\%20Final\%20Report\%20-\%20Oct\%202012.pdf>; 'Strengthening Oversight and Regulation of Shadow Banking: An Overview of Policy Recommendations', Financial Stability Board (August 2013) i-iii <http://www.financialstabilityboard.org/publications/r_130829a .pdf $>$.

46 'Progress and Next Steps towards Ending 'Too-Big-To-Fail' (TBTF): Report of the Financial Stability Board to the G-20', Financial Stability Board (September 2013) <http://www. financialstabilityboard.org/publications/r_130902.pdf $>$.

${ }^{47}$ Zaring (n 41) 692 stating that: '[The FSB is] meant to oversee many of the others, engaged in their own task-specific work.'
} 
set by the Committee, IOSCO, IAIS and others. ${ }^{48}$ This compendium represents the key standards needed for a resilient financial system. Both the compendium and the division of labour between the various bodies characterise the consolidated model.

The first experiment of the consolidated model was the Financial Services Authority, founded in the UK in 1997. While it is a national body, and not a global regulatory body, this experiment provides additional support for the following discussion of the FSF, given the lack of any other global experiments.

The FSA acquired its responsibilities gradually. In 1998 it became responsible for banking supervision, a responsibility transferred from the Bank of England; in 2000 it accepted responsibility for securities supervision and in 2004-2005 for insurance regulation. ${ }^{49}$ The FSA's original objective was to unite UK financial regulation under one authority, operating as a single regulator. However, after the FSA's foundation, claims were made that it was not a united authority, but a collection of (still) separate bodies. It was further argued that the FSA's structure mirrored the traditional sectorial boundaries, so that its 'Handbook' for financial regulation was only an assemblage of rules, and not a coherent framework developed by the FSA. ${ }^{50}$

The chief criticism was that the FSA was not a true 'mega-regulator', but operated in a way similar to the consolidated model. As it happens, the FSA was unable to make a true change in England's financial architecture, which remained split between different regulators, despite being formally subject to a single authority. The FSA was abolished in 2010, and the aftermath of its abolition proves that the criticism was correct, as the areas of responsibility were divided again. Its mandate of prudential regulation was transferred back to the Bank of England and its mandate regarding consumer protection was transferred to the Financial Conduct Authority. ${ }^{51}$ The FSA's abolition moved

\footnotetext{
48 The list of standards included in the compendium is available at 'The Compendium of Standards', Financial Stability Board <http://www.fsb.org/work-of-the-fsb/about-thecompendium-of-standards/>.

49 'History', Financial Services Authority (Web Page, 14 June 2014) <http://www.fsa.gov.uk/ about/who/history>.

${ }^{50}$ Joseph J Norton, 'Global Financial Sector Reform: The Single Financial Regulator Model Based on the United Kingdom FSA Experience: A Critical Reevaluation' (2005) 39(1) International Lawyer 15, 32-3.

${ }^{51}$ The Financial Conduct Authority was established in 2013, primarily to protect consumers in financial markets: 'About the FCA', Financial Conduct Authority (Web Page) $<$ https://www. fca.org.uk/about/the-fca>.
} 
England to the twin-peaks model. ${ }^{52}$ It seems safe to say that the FSA's inability to supply coherent and effective financial regulation was a major reason for its abolition.

The second implementation of the consolidated model confirms that the ineffectiveness of this model was not unique to the FSA. In 1999 a new global body was established, the Financial Stability Forum ('FSF'). Its establishment followed the financial crisis in Asia, which had started in 1997. A major lesson learned from the Asian crisis was that global regulation should be implemented in a more coercive way in national regulation. Since global regulation is formulated by experts, it is more immune than national regulation to the political pressures that were seen as a major cause of that crisis..$^{53}$ The FSF was supposed to function as a joint forum for the different regulatory bodies with a view to improving the enforcement of the global regulation. Over the years, the FSF issued a number of reports, and held several meetings. Unfortunately, the FSF's destiny was no better than that of the FSA in the UK, as the FSF is regarded as a grand failure. The painful proof of its failure was that the UK was not immune to the GFC, which the FSF was in charge of preventing but did not even see coming. ${ }^{54}$ In hindsight, warning signs existed, such as the low level of activity initiated by the FSF and its little, if any, influence on financial regulation.

The resemblance between the FSF and the current FSB, a body founded on the platform of the FSF, is recognisable. Both were established after a crisis and were trying to meet the need for greater unity in global architecture. Both kept the main burden on the shoulders of the regulatory bodies, while trying to improve cooperation between global regulators and the enforcement of their 'soft law' products. Both the FSF and the FSB act primarily as supervising authorities. It is true that the FSB is not identical to the FSF; on the contrary, changes - such as an increase in the number of participants and a broadening of its mandate - were made in order to improve its function, based on the

52 For the abolition of the FSF see Financial Conduct Authority (Web Page, 2019) $<$ www.fsa.gov.uk $>$. See also Eilis Ferran, 'The Break-Up of the Financial Services Authority' (2011) 31(3) Oxford Journal of Legal Studies 455, 455-65.

${ }^{53}$ Barry J Eichengreen, Toward a New International Financial Architecture (Peterson Institute for International Economics, 1999) 10-12 and 32-4.

${ }^{54}$ For a discussion of the failure of the FSF see Enrique R Carrasco, 'The Global Financial Crisis and the Financial Stability Forum: The Awakening and Transformation of an International Body' (2010) 19(1) Transnational Law and Contemporary Problems 203, 205-8. See also Brummer (n 24) 266 (stating that: 'The 2008 financial crisis ... also unveiled with tragic clarity that the national and international regulations in place prior to the crisis to ensure global financial stability were far from adequate.') and David Zaring, 'International Institutional Performance in Crisis' (2010) 10(2) Chicago Journal of International Law 475, 485, 497, 503. 
lessons from the FSF's failure. However, the FSB shares with the FSF the fundamental characteristic of being a supervisory body, in a way that raises serious doubts regarding the FSB's ability to rise above its predecessor. Even though the changes made are likely to improve the function of the FSB, ${ }^{55}$ the basic flaws inherent in this consolidated model, as pointed out above, call for further investigation. ${ }^{56}$

After the GFC the separated regulatory bodies - the Committee, IOSCO and IAIS - continue to create most of the global financial regulation. This enables the expertise needed to handle the complexity of each financial field to be brought to bear. At the same time, the fact that the same regulatory bodies that created the regulation before the crisis are still the ones creating it now is worrisome. If the occurrence of the crisis showed the inability of those bodies to even mitigate it, the lack of a change in the regulating bodies should raise concern.

Moreover, the regulatory structure is still a fragmented one. The establishment of the FSB should (and probably will) contribute to a more coherent supervision, but will the FSB make it coherent enough? A supervisory body may be able to close up some of the holes in financial regulation, but it might not be able to completely reconstruct a piecemeal regulation. If the current structure is still fragmented, the perceived effectiveness of the regulation produced by it is another source of concern. ${ }^{57}$ In order to affirm or dismiss this concern, three segments of current regulation will be examined: 1) the liquidity coverage ratio - a part of the Basel III framework for banks, 2) the regulation of MMFs, and 3) the regulation of repos - all performed under the supervision of the FSB. These segments were chosen since they represent the most novel and best parts of the new regulation after the crisis. Additionally, as these segments come from different financial fields, and were created by different regulators, they enable a relatively broad view of the post-crisis regulation.

\section{B Fragmented Contents}

During the GFC, it became evident that the phenomenon known as a 'run on the bank' had expanded to other financial fields. A 'run on the bank' is an event in which many depositors withdraw their deposits from their bank, in a very

\footnotetext{
${ }^{55}$ Helleiner, What Role for the New Financial Stability Board (n 31) 284-85.

56 That is not to say, of course, that no change is better, or to recommend returning to three separate specialised authorities.

${ }^{57}$ For pointing out that this model at the national level ('lead regulator') is not an effective model, see Pan, Structural Reform of Financial Regulation (n 33) 822. For a general connection between structure and outcomes see Broz and Frieden (n 3) 330.
} 
short period of time. A bank does not hold enough liquid assets to fulfil all of its obligations at once. The essence of a bank's activity is the performance of maturity transformation ('MT'), which is lending long while borrowing short, profiting from the interest difference. A bank works at 'fractional reserve' (that is, it keeps only a certain portion of its assets available), meaning that the bank can redeem only a part of requests accepted at any given time.

A 'run' on a bank can cause the deterioration of a stable bank, just because of rumours about its supposedly poor financial situation. In addition, a 'run' on one bank, in conjunction with asymmetric information regarding the quality of other banks' loan portfolios, can spread to other banks, and cause a 'bank panic'. From the banking system, the panic can develop into a far wider economic crisis, due to links between the financial system and the real economy. ${ }^{58}$

As this phenomenon is quite well known in the banking sector, three strategies have been developed to cope with it: 1) the central bank's role as lender of last resort, 2) deposit insurance (usually provided by a governmental institution) and 3) capital ratios that banks must maintain. The first two offer liquidity, or a solid guarantee to provide it, as a solution to the troubled bank. Providing liquidity, or the guarantee of it, could mitigate the effect of the 'first mover advantage' ${ }^{59}$ The third solution tries to keep the banks generally more solvent, but does not handle a lack of liquidity, which is the source of a run on the bank. Understanding that capital ratio is not sufficient to handle a bank run, the capital rules of Basel II were supplemented in the Basel III framework with new liquidity demands. ${ }^{60}$

Until the GFC the phenomenon of runs on the financial institution was thought to affect mainly banks. However, the recent crisis revealed the susceptibility of other financial institutions to a similar 'run' syndrome. As I have explained elsewhere, it turned out that a 'run on the bank' can happen, and indeed did

\footnotetext{
58 Douglas W Diamond and Philip H Dybvig, 'Bank Runs, Deposit Insurance, and Liquidity' (1983) 91(3) Journal of Political Economy 401; Carmen M Reinhart and Kenneth S Rogoff, 'The Aftermath of Financial Crises' (Working Paper No 14656/2009, National Bureau of Economic Research, January 2009) <http://www.nber.org/papers/w14656>.

59 This incentive to withdraw money early (to be the 'first mover') arises as the bank does not have enough cash to fulfil all of its obligations.

${ }^{60}$ For the difference between solvency and liquidity see Anat R Admati et al, 'Fallacies, Irrelevant Facts, and Myths in the Discussion of Capital Regulation: Why Bank Equity Is Not Expensive' (Working Paper No 86/2011, Rock Center for Corporate Governance at Stanford University, 22 October 2011) <http://papers.ssrn.com/sol3/papers.cfm?abstract_id=1669704>.
} 
happen, in MMFs, which are collective investment vehicles. ${ }^{61}$ They are funds in which an investor acquires shares redeemable on demand. Each share reflects the investor's relative portion of the fund's assets. MMFs invest in money market instruments, investments considered safe and relatively liquid.

Despite the formal difference between MMFs and banks, they both share a similar mode of operation at MT, which is the dominant cause of a potential run. ${ }^{62}$ During the last crisis MMFs experienced a 'run on the fund' ${ }^{63}$ The most prominent example was the run on the Reserve Primary Fund, a major US MMF which managed assets worth USD 62 billion, leading to its liquidation. This fund collapsed after receiving USD 60 billion in redemption requests in the four days following the collapse of Lehman Brothers, despite the fact that its exposure to Lehman's toxic assets amounted to only USD 785 million. ${ }^{64}$ The run on this fund led to runs on other funds, so that in one week, USD 300 billion were withdrawn from MMFs. ${ }^{65}$ In the summer of 2011, a 'slow-motion run' hit the prime MMF sector as fears about European sovereign debt problems mounted, causing redemptions of more than USD 170 billion in approximately two months. The 'run' phenomenon also appeared during the crisis in other financial fields, such as repos, as will be further discussed below.

Appearing in different financial sectors, the 'run on the bank' problem offers an exceptional case-study of the degree of coherence that global regulation has achieved since the crisis. Given the extensive efforts to harmonise global financial regulation, one could expect that, after the crisis, a similar problem will result, with a similar regulatory solution (with the appropriate adjustments, of course). As a short comparison of the regulatory treatment of the 'run on the

${ }^{61}$ Dalit Flaiszhaker, 'A Macroprudential Perspective on the EU Regulation of Money Market Funds' in Edoardo Chitti and Giulio Vesperini (eds), The Administrative Architecture of Financial Integration: Institutional Design, Legal Issues, Perspectives (il Mulino, 2015) 2735.

${ }^{62}$ Morgan Ricks, 'Regulating Money Creation after the Crisis' (2011) 1 Harvard Business Law Review 75, 104-6. For a (restrained) acknowledgement that MMFs operate by fractional reserve see Jonathan Macey, 'Reducing Systemic Risk: The Role of Money Market Mutual Funds as Substitutes for Federally Insured Bank Deposits' (2012) 17(1) Stanford Journal of Law, Business and Finance 131, 153-4.

${ }^{63}$ Technical Committee of the International Organization of Securities Commissions, 'Money Market Fund Systemic Risk Analysis and Reform Options: Consultation Report' ('MMF Consultation Report') IOSCO (27 April 2012) 5-6 <https://www.iosco.org/library /pubdocs/pdf/IOSCOPD379.pdf $>$.

${ }^{64}$ Jonathan W Lim, 'Untangling the Money Market Fund Problem: A Public-Private Liquidity Fund Proposal' (2013) 19(1) Stanford Journal of Law, Business and Finance 63, 75-7.

${ }^{65}$ MMF Consultation Report (n 63) 56. 
bank' phenomenon in three different sectors shows, this is not the case with post-crisis global financial law; it is still fragmented.

One prominent reform introduced by the Basel III framework is the introduction of new liquidity and funding demands. ${ }^{66}$ The new liquidity demands are divided into two parts, ${ }^{67}$ the first being the liquidity coverage ratio ('LCR'), implemented in all 27 Committee member jurisdictions. ${ }^{68}$ The LCR is intended to assure the ability of a bank to survive a short-term crisis. Its basic rationale is that, if a bank holds enough liquidity to last through a 30 day crisis, this will enable its managers and the regulators to consider proper future steps needed to prevent its collapse.

The LCR requires a bank to hold a sufficient stock of high-quality liquid assets ('HQLA') to cover its total net cash outflows over the next 30 days. The ratio between the HQLA (the numerator) and the net outflows (the denominator) should equal at least $1 .{ }^{69}$ By equalising the potential obligations the bank will need to meet in a one month period to its liquid assets (that is, assets that are available or can be made available immediately without great loss of value), this formula guarantees that the bank will be more resilient to a run scenario. As a result of applying the LCR, if the bank wishes to take on more obligations, it needs to have more liquid assets. The LCR rule specifies which assets can be regarded as HQLA. For example, cash and central bank reserves, or sovereign bonds (subject to certain conditions and deductions), are the highest level of assets. The rule also calculates the 'net cash outflows' by subtracting the income cash flow (such as payments and interest) from the cash outflows (such as deposits). In addition, to prevent banks from relying fully on a future cash income, a bank needs to hold HQLA amounting to at least $25 \%$ of its cash outflows (regardless of the cash inflows). ${ }^{70}$

\footnotetext{
${ }^{66}$ Basel Committee on Banking Supervision, Basel III: The Liquidity Coverage Ratio and Liquidity Risk Monitoring Tools (January 2013) ('LCR') <https://www.bis.org/publ/bcbs 238.pdf $>$.

${ }^{67}$ See Andrew W Hartlage, 'The Basel III Liquidity Coverage Ratio and Financial Stability' (2012) 111(3) Michigan Law Review 453, 462-5.

${ }^{68}$ For the ratio implementation as of November 2018 see Basel Committee on Banking Supervision, 'Implementation of Basel Standards', Bank for International Settlements (November 2018) <https://www.bis.org/bcbs/publ/d453.pdf $>$.

${ }^{69}$ The LCR also includes five monitoring tools, designed to provide a complete picture of the bank business: LCR (n 66) [174]-[176].

${ }^{70}$ Ibid [144].
} 
The second part of the liquidity framework is the net stable funding ratio ('NSFR'), whose implementation process was set at the end of 2017. ${ }^{71}$ This rule focuses on improving the funding origins of the bank, with the intention of enhancing its liquidity in the timeframe of a year. Assuring more stable funding will minimise obstacles in funding that may erode the bank's liquidity, for example in the event that the funder itself experiences difficulties in providing the relied-upon funding to the bank. ${ }^{72}$ To create a stable funding profile, the NSFR limits the bank's capacity to rely on short-term wholesale funding which is considered relatively risky, and encourages a better evaluation of the funding sources inside and outside the bank's balance.

The NSFR is designed to counteract the bank's natural inclination to enlarge its leverage (since high leverage means potentially higher profits), by making it more difficult for the bank to use cheap and unstable funding sources. The NSFR sets a basic formula which upholds the ratio between the 'available stable funding' and the 'required stable funding' at 1 or more. For calculating the available stable funding, the obligations of the bank are divided into five categories based on the stability of the funding, and the required funding is divided into seven categories, based on the probability that the asset will need to be funded in a period of one year.

Two assumptions underlie the methods used to calculate the 'available' and 'required' funding, to show the degree of stability of each obligation. Longterm funding is considered more stable than short-term funding, and retail (and small business) funding is regarded as more stable than wholesale funding. ${ }^{73}$

Integrating both parts, the liquidity framework deals with both sides of the bank's risk-creating activity. The LCR addresses the bank's assets, and obliges it to hold enough of them for times of stress. At the same time, the NSFR handles the obligations, and forces the bank to rely on more stable funding sources, to prevent a situation in which the bank can no longer fund the loans it has granted.

\footnotetext{
71 'Basel III: The Net Stable Funding Ratio', Basel Committee on Banking Supervision (Consultative Document, January 2014) <http://www.bis.org/publ/bcbs271.pdf $>$ ('NSFR'). As of November 2018, 25 members of the Committee have issued final or draft rules to implement it: see Basel Committee on Banking Supervision (n 68).

${ }^{72}$ A bank acquires short-term funding (in the form of deposits or loans from other financial institutions), and lends the money for longer periods. If the short-term funding is stopped, the bank will not be able to continue to refinance its outstanding loans, meaning it will be insolvent.

${ }^{73}$ NSFR (n 71) [12].
} 
The need to set liquidity rules at the global level is due to liquidity's costs. Keeping a higher stock of HQLA is equivalent to keeping some of the money idle or at least not as profitable as it could have been (if lent long). The inability to use these assets to extend more loans is costly since loans carry profit, in the form of interest. By the same token, a more stable funding is usually more expensive to the bank. These costs, unless demanded uniformly at the global level, can cause a race to the bottom between states, just as the capital adequacy issue did, with potential for similar harmful consequences. It seems as if the liquidity framework could be effective in mitigating a run on the bank, as it limits the bank's risk-creating activity and provides for a liquidity solution to be used in times of stress. ${ }^{74}$

However, these effective liquidity demands are lacking in the regulatory treatment of MMFs. Following a run on MMFs, and in accordance with the methodology established by the post-GFC architecture as described above, the FSB ordered IOSCO to prepare recommendations for the MMF sector. MMFs fall within IOSCO's field of expertise, being investment funds. ${ }^{75}$ In October 2012, after publishing a 'consulting report', IOSCO published its recommendations. The recommendations are divided into six major parts, the relevant ones of which will be described.

First, the recommendations identify an MMF as every fund designed to promise a daily liquidity and yield. This relatively broad definition is intended to encompass every fund which imitates MMFs, even if it operates by a different name, so as to prevent regulatory arbitrage. ${ }^{76}$ Second, the funds are to be allowed to be invested only in specific types of assets - relatively short-term ones - as a means of mitigating the maturity mismatch. ${ }^{77}$ The fifth recommendation relates to 'liquidity management', the sixth recommendation deals with issuing 'know your investor' policies, and the eighth

\footnotetext{
${ }^{74}$ Depending, naturally, on other issues such as enforcement.

${ }^{75}$ As stated in the recommendations: 'The September 2008 run on some money market funds (MMFs) alerted regulators to the systemic relevance of MMFs. Although MMFs did not cause the crisis, their performance during the financial turmoil highlighted their potential to spread or even amplify a crisis. ... [C]oncerns remain regarding the stability of the money market fund industry and the risks it may pose for the broader financial system. In this regard, the Financial Stability Board (FSB) asked the International Organization of Securities Commissions (IOSCO) to undertake a review of potential regulatory reforms of MMFs that would mitigate their susceptibility to runs and other systemic risks and to develop policy recommendations': IOSCO Policy Recommendations (n 45) 3.

${ }^{76}$ IOSCO Policy Recommendations (n 45) pts 1-3.

${ }^{77}$ For a conservative fund it is recommended that the MT of total assets should not exceed 60 days, and the MT of each instrument should not exceed 120 days: IOSCO Policy Recommendations (n 45) 11 (Recommendation 2).
} 
recommendation deals with periodic stress tests. The seventh recommendation sets a minimum threshold of assets that each fund should hold in a very liquid form (such as a deposit in a known bank) to enable the fund to immediately answer redemption requests. Yet the recommendation does not specify the exact amount of assets the fund should hold or how this threshold should be determined by the regulators. Without such accurate definitions, the recommendation could not be effective enough. ${ }^{78}$ The recommendations state that, in order to deal with a 'run' on the fund, the fund should have means to hold redemption requests for a certain period of time ${ }^{79}$ and should refrain from concentrating too many of the fund's shares with one shareholder. Additionally, the recommendations set disclosure requirements and accounting methods to be used in calculating the value of the fund's shares. ${ }^{80}$

Hence, a comparison of the new global regulation of banks with the new global regulation of MMFs shows crucial differences. Despite the similarity in their modes of operation and in their exposure to a run, as was evidenced in the GFC, the adopted solutions are different. Whereas the regulation of banks includes stringent liquidity and leverage demands, these demands are not made of MMFs. It should be mentioned that the similarity between banks and MMFs was not disregarded by IOSCO. An earlier draft of the recommendations considered the possibility of transforming MMFs into 'special purpose banks', due to their functional similarity and exposure to a run. ${ }^{81}$ In the final recommendations, however, this solution was not adopted. A similar choice, to prescribe different solutions to the 'run' phenomenon according to the type of institution, was made in the regulation of repos.

A repo is a repurchase transaction in which the 'borrower' (for example, a bank) sells an asset (for example, bonds) to the 'lender'. The seller/borrower commits to buying back the asset at the end of an agreed period of time, at an agreed price. The price reflects an increase compared to the initial sum 'paid' for the asset by the buyer/lender, an increase equal to the interest on a loan. Until the buy-back of the asset (that is, the repaying of the loan), it stands as collateral. ${ }^{82}$

\footnotetext{
${ }^{78}$ Ibid pt 7.

${ }^{79}$ Ibid pt 9.

${ }^{80}$ The 'amortised cost' accounting method, and its implications for the price of each of the fund's shares, will not be discussed. IOSCO recommends that most of the funds will be of variable price as opposed to stable pricing method, which is more prone to a run: ibid pts $4-5,10,13-$ 14.

${ }^{81}$ MMF Consultation Report (n 63) 20.

${ }^{82}$ For the collateral to cover the full amount of the loan, the lender demands and accepts assets worth more than the initial sum given. Therefore, the asset is not fully used, since $100 \%$ of it is used to cover a loan worth, for example, only $90 \%$.
} 
The same collateral can support multiple transactions (a phenomenon described as 're-hypothecation' or 're-use'), 'just as one dollar of cash can lead to a multiple of demand deposits at a bank' ${ }^{83}$ These characteristics of repo transactions make them vulnerable to the run syndrome, as these transactions are based on a method similar to fractional reserve. Therefore, it has been argued that, during the GFC, we have witnessed a 'run on repos' ${ }^{84} \mathrm{~A}$ similar rationale led the FSB to justify the creation of new regulation of repos (and of securities lending more generally):

[T] he use of securities lending and repos can lead to 'bank-like' activities such as creating 'money-like' liabilities, carrying out maturity/liquidity transformation, and obtaining leverage, including short-term financing of longer-term assets, some of which may run the risk of becoming illiquid ... ${ }^{85}$

Consequently, the recommendations published by the FSB in 2013 identify two groups of risks that repo transactions generate: 1) risks originating from the shadow banking sector, as it is not fully supervised by existing regulation, and 2) risks that repo transactions pose for the banking system, mainly due to the high involvement of banks in this market. The recommendations for repo transactions deal with three major topics: 1) improving the transparency of the transactions, 2) the re-use of collateral, and 3) changing the markets for secured financing towards central clearing. ${ }^{86}$ The two relevant recommendations for our discussion are the sixth and the tenth.

The sixth recommendation requires the national authorities to set a minimum threshold for the re-hypothecation of collateral. In the tenth recommendation, the FSB recommends that the national authorities evaluate the costs and benefits of setting up a central counterparty clearing system, in which all members perform their repo transactions with one central body. The central clearing is supposed to lower the interdependency between financial

${ }^{83}$ Gary Gorton and Andrew Metrick, 'Haircuts' (2010) 92(6) Federal Reserve Bank of St. Louis Review 507, 510.

${ }^{84}$ Ibid. The authors' detailed explanation is that on occasions of market instability, when information regarding the financial state of each specific institution is lacking, the collateral undergoes large 'haircuts'.

85 'Strengthening Oversight and Regulation of Shadow Banking: Policy Framework for Addressing Shadow Banking Risks in Securities Lending and Repos' ('Repo Recommendations'), Financial Stability Board (29 August 2013) $4<$ http://www.financial stabilityboard.org/publications/r_130829b.pdf $>$.

${ }^{86}$ Recommendations $1-5$ handle the need to enhance the information gathering of the transactions performed and recommendations 8-9 set rules for the proper evaluation of the securities: Repo Recommendations (n 85) 7-19. 
institutions, as the transactions are performed in a net manner (and not bilaterally).

As can be noticed, the regulatory methods of supervising MMFs and repos are very similar. Both methods recommend that the national authorities set a level of liquid assets that must be maintained or a level at which the re-use of collateral is permissible, respectively, but neither specifies what exactly this level should be. Both recommendations focus mainly on the transparency/disclosure requirements, which may be important in themselves, but cannot deal with a 'run'. ${ }^{87}$ And neither limits the risk-creating activity of MMFs and repos.

The banking framework described above limits the possibility of a bank granting more loans (depending on its level of liquid assets). By contrast, neither of the shadow banking recommendations described in the framework limits the option of performing more risk-creating activities. And neither of the recommendations handles liquidity solutions, as done by the liquidity framework applied to banks, described above.

These three samples - the liquidity coverage ratio applied to banks, the regulation of MMFs, and the regulation of repos - together form a unified understanding of the global regulation after the crisis. This regulation presents different solutions to a similar problem, depending on the type of institution. As explained above, regulatory arbitrage between states can have damaging outcomes with regards to stability. In a similar manner, regulatory arbitrage between financial sectors can have damaging outcomes. ${ }^{88}$ The reason is basic: prohibiting (or limiting) a dangerous activity in one field can push it towards another field, from which it can infect all other sectors. Regulatory arbitrage is a worrisome phenomenon, particularly in the financial field, since it creates 'holes' in the supervision coverage. ${ }^{89}$ The need to cast the regulatory net wide by developing macro-prudential policy, as explained above, is meant to prevent the circumvention of limitations imposed on one kind of financial institution by the use of other kinds of institution or transaction. However, as the examination

\footnotetext{
${ }^{87}$ That is because the only way to prevent a run, or to mitigate it after it has started, is to provide guarantees for the money invested in financial institutions.

${ }^{88}$ As the FSB states: Repo Recommendations (n 85) 2.

${ }^{89}$ One could argue that the difference in the activities of each sector calls for different solutions. This may be true (to some extent), in regard to some needed adjustments. Yet this argument is not relevant since it does not deal with the effectiveness problem, and especially not with the regulatory arbitrage problem. For regulatory arbitrage in a financial system see Erik F Gerding, Law, Bubbles, and Financial Regulation (Routledge, 2013).
} 
of three segments of the post-crisis regulation has shown, even after the GFC financial regulation continues to be fragmented.

\section{Global Financial Regulation - A Unique Democratic Deficit}

Two possible explanations can be offered for this fragmented nature of the current architecture. The first is founded on political considerations. It could be that the bodies existing before the crisis were not enthusiastic about the idea that they needed to be abolished (or fundamentally reshaped). These institutions preferred to preserve their existence and power, and applied pressure against a dramatic change. For example, any acknowledgment of the similarity between MMFs and banks may cause the removal of the former from IOSCO's sphere of responsibility. For IOSCO, this would mean losing a significant amount of its influence. Yet public opinion demanded a change that would implement the lessons of the GFC and could not be ignored by the architects. This caused what de Tocqueville sharply described nearly 200 years ago:

Under these circumstances, the result was, that the rules of logic were broken, as is usually the case when interests are opposed to arguments. A middle course was hit upon by the legislators, which brought together by force two systems theoretically irreconcilable. ${ }^{90}$

The result of the colliding political considerations was a convergence of the multiple regulator model with the single regulator model, to create the consolidated model at the global level. This convergence enabled the architects to respond to the need for change without rocking the foundations of the previous system. According to this explanation, the FSB's configuration is a compromise between two models, structured in such a way that not only does it not have the virtues of either, but that it has inherited many of their vices.

Another possible explanation is a conceptual fixation on the part of the regulators. According to this explanation, the absence of change derives from the regulators' belief that their way of observing the financial system is the correct one. Regulators prefer to cling (even unknowingly) to the same old fundamentals, allowing no room for the contemplation of completely fresh ideas. This could explain, for example, the difference between the regulation of banks and of shadow banking (MMFs and repos). Regulators continue to follow the formal definitions of financial institutions - if it is a 'bank', a specific regulation by a specific regulator should apply, and if it is a 'fund', a different

\footnotetext{
${ }^{90}$ Alexis de Tocqueville, Democracy in America, tr Henry Reeve (Sever and Francis, 1863) vol I, ch VIII 'The Federal Constitution' 148.
} 
regulation should be implemented. Hanging on to these formal definitions blinds the regulators to the true (similar) activity of the two types of institution, and prevents regulators from adjusting the regulation accordingly. In this mode of thinking, the only plausible way forward is to make changes to an already existing framework, as opposed to rethinking everything anew. ${ }^{91}$

That is not to say, of course, that a change is always desirable. There are situations in which a change can be for the worse. But in the case of the global financial architecture, as the GFC has shown, a change is undoubtedly needed. ${ }^{92}$ It seems that the fragmented architecture, regardless of the immediate cause of its fragmentation, will not likely be able to prevent the next crisis. ${ }^{93}$ Given the harsh consequences of a financial crisis, a fragmented global architecture representing a flaw in the primary gatekeeper against such a crisis - is very worrisome.

\section{The Paradox of Global Financial Regulation}

Part $\mathrm{V}$ above analysed the regulatory efforts from the effectiveness angle, in order to appreciate their expected success. For this purpose, the Part focused on the 'risk-potential' aspect of the financial activity of credit creation. Yet, representing the core of the financial system, the issue of credit creation cannot be narrowed down to this one aspect of risk; instead, it requires a widening of the examination lens.

The primary goal of global financial regulation is to provide a level playing field of prudential regulatory standards, as explained in Part II above. Therefore, implementing global financial regulation does limit the sovereignty of the adopting state to some extent, as that state cannot choose freely its own

\footnotetext{
${ }^{91}$ For a similar line of explanation, see Paul Krugman, 'How Did Economists Get It So Wrong?', New York Times (online, 2 September 2009) <http://www.nytimes.com/2009/09/06/magazine/ 06Economic-t.html?pagewanted $=$ all\&_r $=0>$.

${ }^{92}$ See also Eric Helleiner and Stefano Pagliari, 'Between the Storms: Patterns in Global Financial Governance, 2001-07' in Geoffrey Underhill, Jasper Blom and Daniel Mügge (eds), Global Financial Integration Thirty Years On: From Reform to Crisis (Cambridge University Press, 2010) 42; Eric Helleiner, 'Crisis and Response: Five Regulatory Agendas in Search of an Outcome' [2009] 1 Internationale Politik und Gesellschaft (International Politics and Society) 11 and Eric Helleiner, 'Reregulation and Fragmentation in International Financial Governance' (2009) 15(1) Global Governance 16.

${ }^{93}$ Based on the inherent instability of the financial system, it seems reasonable to assume that another crisis will happen. The relevant question is not if it will happen, but what is being done to prevent or mitigate it. On the abovementioned inherent instability see Hyman P Minsky, The Financial Instability Hypothesis (Working Paper No 74, Jerome Levy Economics Institute, May 1992) <http://papers.ssrn.com/sol3/papers.cfm?abstract_id=161024>.
} 
method of stability; yet global regulation is not intended to greatly influence the state's discretion in managing its economy. This apparent trade-off is presented as a 'win-win' situation. In exchange for giving up some relatively small part of its sovereign rights in the technical field of financial regulation in favour of experts at the global level, the state benefits from a stable global financial system. ${ }^{94}$

This trade-off may be compromised if global regulation is unable to provide effective regulatory coverage. In that case, it could be that the price paid is higher than the expected stability gain. A few preliminary words on the general function of a financial system in a state's economy are needed to better appreciate the price of such a trade-off.

The essential objective of every financial system is to supply the credit needed to sustain a productive economy. It performs this task by intermediating between those seeking a yield from money they currently hold ('savers'), and those who lack money but need finance for intended economic activity ('borrowers'). In its simplified version, 'banking' is financial intermediation transferring money from savers to borrowers who need money for a productive purpose, such as financing an invention, building, or manufacturing. ${ }^{95}$ The net profit generated from this economic activity will be shared by the borrower with the bank (which in turn will share it with its savers), in the form of interest. The 'gross' profit to society in general of this intermediation is derived from the creation of new firms, new products, and new jobs. Without the initial access to credit, the entrepreneur will be unable to materialise an idea. ${ }^{96}$ An efficient financial system is a system which collects credit and then channels it from the financial system into the real economy. In this regard, the risk inherent in the financial activity (that is, the creation of credit) can be justified since it is a necessary component of a functioning economy.

\footnotetext{
${ }^{94}$ For an accurate description of the interest that a state has in cooperating with the IMF, a description that is also relevant to the architecture in general, see Robert Hockett, 'From Macro to Micro to "Mission-Creep": Defending the IMF's Emerging Concern with the Infrastructural Prerequisites to Global Financial Stability' (Research paper No 06-038, Cornell Law School, 2006) $182<$ http://scholarship.law.cornell.edu/lsrp_papers/62>. This does not contradict the incentive to defect, described above, in order to achieve more benefits.

${ }^{95}$ With the development of banking, banks no longer act as mere intermediaries. They are also able to create credit almost anew, operating by virtue of fractional reserve banking. For further discussion of this see L Randall Wray, Modern Money Theory: A Primer on Macroeconomics for Sovereign Monetary Systems (Palgrave MacMillan, $2^{\text {nd }}$ ed, 2012) ch 3.

${ }^{96}$ Walter Bagehot, Lombard Street: A Description of the Money Market (Henry S King, 1873) 6-20. See also Robert Hockett, 'Bretton Woods 1.0: A Constructive Retrieval for Sustainable Finance' (2013) 16(2) New York University Journal of Legislation and Public Policy 401, 420 5.
} 
This linkage to the real economy is supposed to be at the heart of any financial intermediation. Yet, despite the similarities in functions described above, it could be argued that the shadow banking sector has looser connections to the real economy than banks do. The shadow banking sector is composed primarily of investment banks and other financial institutions, performing high-end sophisticated financial activity with advanced financial instruments. The exact contribution of the sizable shadow banking sector to the real economy is questionable, at best. ${ }^{97}$ What is clear is that the sector is much less accessible to all parts of the population than banks are. ${ }^{98}$

The rise of shadow banking can be pictured as a part of a larger phenomenon, namely 'financialisation'. ${ }^{99}$ Financialisation occurs when the financial system grows to a point where it becomes estranged from the real economy. Shadow banking can be regarded as a kind of 'evolution' of the 'traditional' financial activity, needed in order to accommodate modern conditions. On the one hand, shadow banking can be used to enlarge the amount of available credit and to lower its price. ${ }^{100}$ Yet, if it becomes the primary focus of the financial system and attracts much of its activity, it could mean that credit is used more for speculative activity or for investing in other financial instruments. Whereas banks have a rather direct link to the real economy through deposits and loans,

${ }^{97}$ The contribution of shadow banking is under current debate within the economic literature: see Emmanuel Farhi and Jean Tirole, 'Shadow Banking and the Four Pillars of Traditional Financial Intermediation' (Working Paper 23930, NBER, October 2017) $<$ http://www.nber.org/papers/w23930.pdf $>$. For our purposes here, the simple fact that such contribution is, at the very least, contested, is sufficient.

98 Tamara Lothian, 'After the Crisis: Institutional Innovation and the Alternative Futures of American Finance' (Working Paper No 386, Columbia University, 15 June 2011) 15-16 $<$ http://works.bepress.com/tamara_lothian/5/>. Tamara Lothian and Roberto Mangabeira Unger, 'Crisis, Slump, Superstition and Recovery: Thinking and Acting beyond Vulgar Keynesianism' (Unpublished paper, Columbia University, 1 March 2011) $<\mathrm{http}: / /$ works.bepress.com/tamara_lothian/10/>. See also Mian and Sufi (n 25).

${ }^{99}$ For a thorough description of 'financialisation' in the US, including an examination of relevant data and a consideration of counter-arguments, see Greta R Krippner, Capitalizing on Crisis: The Political Origins of the Rise of Finance (Harvard University Press, 2010) ch 2. Krippner also demonstrates the consequences of financialisation by showing that in the 1950s-1960s the financial system held $10-15 \%$ of the total profits in the US economy; in the 1980s this percentage rose to $30 \%$, reaching its highest point of $40 \%$ in 2001 . See also Verdier (n 8) 1415 , claiming that in 2007 global financial activity was $343 \%$ of the world GDP.

${ }^{100}$ See, eg, 'Strengthening Oversight and Regulation of Shadow Banking: Policy Framework for Strengthening Oversight and Regulation of Shadow Banking Entities', Financial Stability Board (August, 2013) ii <http://www.financialstabilityboard.org/publications/r_130829c. pdf $>$ : 'Such intermediation, appropriately conducted, provides a valuable alternative to bank funding that supports real economic activity. But experience from the crisis demonstrates the capacity for some non-bank entities and transactions to operate on a large scale in ways that create bank-like risks to financial stability...' (emphasis added). 
the connections between shadow banking and the real economy are indirect and much more questionable. The shadow banking sector, in general, does not engage directly with people looking to invest or in need of money, but rather engages with 'behind the scenes' financial activity. ${ }^{101}$ Financialisation materialises from the overgrowth of the shadow banking sector, since, as the shadow banking sector grows, the financial system grows - growth that is not necessarily accompanied by real economic growth.

The new global regulation described above is expected to encourage future credit creation within the shadow banking sector. Due to the regulatory limits imposed on banks, the creation of credit will likely take place in the shadow banking sector, leading to its continuing growth. Indeed, in recent years, the shadow banking sector increased at about $8 \%$ per year, nearly double the growth rate of banks. It is currently responsible for about $30 \%$ of global financial assets, whereas banks are responsible for about $40 \%{ }^{102}$ The limits imposed by global regulation on the credit supply in the banking system, particularly the liquidity demands, may lower the risk levels in the banking system. Yet, the regulation is constraining the creation of credit in the banking system, while simultaneously enabling its creation almost freely in the shadow banking sector. As described above, there are almost no limitations to credit creation in MMFs, and there are no such limitations on repos.

Encouraging the growth of the shadow banking sector, the new global regulation is likely to boost the process of financialisation. It will enlarge the disconnect between the financial system and the real economy and push them further apart. In this respect, regarding global financial regulation as neutral (that is, as supporting general growth, without influencing its distribution) is misleading. ${ }^{103}$ Roughly speaking, channelling credit to the real economy benefits the working class, whereas using credit for speculative purposes

\footnotetext{
${ }^{101}$ The Bank of England surveyed the revenues of the 10 largest global investment banks in 2013. It determined that about three quarters of their revenues (around USD 140 billion) come from services to the financial system, and only one quarter from services directly to the real economy: Kushal Balluk, 'Investment Banking: Linkages to the Real Economy and the Financial System', Bank of England (Quarterly Bulletin, 9 March 2015) 9-10<https://www.bankofengland. co.uk/quarterly-bulletin/2015/q1/investment-banking-linkages-to-the-real-economy-and-thefinancial-system $>$. Balluk states that there are differences between the activity of traditional banking and shadow banking, as the latter is more involved in sophisticated financial activities.

102 'Global Shadow Banking Monitoring Report 2017', Financial Stability Board (5 March 2018) $<$ https://www.fsb.org/wp-content/uploads/P050318-1.pdf $>$.

${ }^{103}$ See Daphne Barak-Erez and Oren Perez, 'Whose Administrative Law is it Anyway? How Global Norms Reshape the Administrative State' (2013) 46(3) Cornell International Law Journal 455, 483-4, arguing that global regulation, more generally, has a hidden (neo-liberal) ideological dimension that needs to be exposed.
} 
benefits the classes performing these activities: by and large the richer parts of society who own financial assets. Similarly, accessibility to shadow banking and its credit is easier for big firms and richer people. It is no surprise that in recent years we are witnessing growing inequalities between rich and poor. ${ }^{104}$ The empirically-proven general fact that financial regulation affects socioeconomic sectors differently ${ }^{105}$ receives another confirmation from the above inspection of the post-crisis financial regulation.

These consequences are not completely unnoticed by the leaders of the global regulatory architecture. ${ }^{106}$ For example, the decrease in credit creation for the real economy after the crisis has been pointed out as a worrying obstacle to economic recovery. ${ }^{107}$ In particular, the decrease in banking credit and in credit for small businesses is referred to as a problem. ${ }^{108}$ Additionally a correlation between the rise of shadow banking and the current financial system being

\footnotetext{
${ }^{104}$ For an analysis of growing inequality, especially from the 1970s onward, see Thomas Piketty, Capital in the Twenty-First Century, tr Arthur Goldhammer (Harvard University Press, 2014), particularly in figures 10.5 and 10.6. Piketty does not argue that global financial regulation is the only (or even the most influential) cause for the concentration of wealth. It is argued, however, that the infrastructure of the global financial system is responsible for some of its outcomes.

${ }^{105}$ Dani Rodrik, 'Normalizing Industrial Policy' (Working Paper No 3, World Bank, 2008) 6, stating that: 'Financial market imperfections ... are best remedied, the counter-argument goes, by uniform measures that target financial markets ... In practice most interventions, even those that are meant to be horizontal, necessarily favor some activities over others. For example, policies targeted at improving financial intermediation by commercial banks are partial to firms in the formal sector that have access to external finance, and discriminate against small and informal firms.' See also Jonathan Kirshner, 'The Inescapable Politics of Money' in Jonathan Kirshner (ed), Monetary Orders: Ambiguous Economics, Ubiquitious Politics (Cornell University Press, 2003) 3, 16.

106 Broz and Frieden (n 3). For the issue of credit more generally see L Randall Wray, 'Alternative Approaches to Money' (2010) 11(1) Theoretical Inquiries in Law 29. It seems, based on this article, that viewing 'money' as not only a neutral means of exchange necessarily changes the way it should be regulated.

107 'Global Financial Stability Report', International Monetary Fund (October 2013) 65, 66-7 $<$ https://www.imf.org/External/Pubs/FT/GFSR/2013/02/>: 'As expected, higher bank funding costs and lower bank capital have reduced the ability of banks to supply loans, and high debt levels in firms and households (along with lower GDP growth forecasts) have lowered credit demand (and affected credit supply)'. Another example is the increased spread in interest paid for loans above USD 1 million in comparison to smaller loans doubling in the Euro area between 2007 and 2013.

${ }^{108}$ See Bill Allen et al, 'Basel III: Is the Cure Worse Than the Disease?' (2012) 25 International Review of Financial Analysis 159, 163: 'the liquidity requirements in Basel III are forcing banks both to contract their balance sheets and increase their holdings of liquid assets; this means they have to reduce non-liquid assets and restrict credit' (emphasis added).
} 
prone to crises can be pointed to. ${ }^{109}$ Stability in the financial system is a means to promote growth, just as financial crises impede it. However, by turning the 'means' (stability) into the end itself, it seems that global financial regulation is defeating its own greater purpose of providing regulation that supports a stable and efficient global financial system, to the benefit of economic growth. ${ }^{110}$

It should not be thought that I am advocating the end of the shadow banking sector. Rather, my argument is that the regulatory choice made between different forms of financing, by limiting certain forms and allowing others, has implications for the real economy. Global financial regulation is not just bureaucratic regulation carried out by experts finding the best way to mitigate a crisis. Rather, it has a significant influence on how each national financial system is constructed and how the global financial system is constructed. Consequently, global financial regulation has substantial implications for our lives.

The premise of global financial regulation is that it will focus on achieving stability for the benefit of all states (thus justifying its formulation by experts, at the global level), but at the same time will not influence matters such as how much credit will be created in each state or where this credit will be channelled. Those matters are traditionally conceived of as part of domestic monetary policy, based on the specific economic needs and wants of each state. It is harder for this paradigm to be persuasive, however, when it is considered that

\footnotetext{
${ }^{109}$ As experience from the last decades shows, global financial crises are a repeated occurrence. Counterintuitive as it may seem, financial crises tend to affect the low-income sections of society, which are typically the 'borrowers' more than the high-income sections, typically the 'lenders'. In the immediate term, the GFC decreased the value of financial assets. However, due to a general decrease in the value of other assets, it turned out that, in the medium term after the crisis, owners of financial assets actually enlarged their relative portion (using the example of mortgages). Mian and Sufi show that in 1992 the wealth percentage held by the upper class was $66 \%$, in 2007 it was $71 \%$, and in 2010 (that is, after the crisis) it was $74 \%$. On this basis they argue that the recent crisis has enlarged the (existing) gap between rich and poor in the US. They claim that a financial system based primarily on debt (in other words credit), enlarges inequality, since 'debt' affects the lender and the borrower differently. See Mian and Sufi (n 25 ) ch 2 , and $18-25,44-5$ and $76-9$.

110 The underlying assumption that these consequences are unintentional is sufficient for the needs of this article. One could wonder, however, if they serve certain power relationships or hierarchies. See generally Morton J Horwitz, 'The Rise of Legal Formalism' (1975) 19(4) American Journal of Legal History 251.
} 
financial regulation cannot achieve 'only' stability without affecting the real economy. ${ }^{11}$

I claim that global financial regulation has larger implications for a state's financial system than is commonly discussed. Implementing global financial regulation determines not just the prudential level of a state's financial system, but also substantial parts of its economy; implementing global financial regulation means not only giving up the ability to balance stability and competitiveness, but also the authority to decide how to distribute gains, using financial regulation. An understanding of these sovereignty costs leads to serious doubts regarding the legitimacy of global financial regulation regulation which in a continuing process, and especially after the GFC, holds great coercive power. This power may be necessary, yet it still calls for stronger justifications. ${ }^{12}$

The effectiveness of financial regulation is the current chief justification for its creation at the global level, as national law cannot alone handle the challenges presented by the globalised financial system. ${ }^{113}$ This effectiveness-based

\footnotetext{
${ }^{111}$ For the claim that the 'open-economy trilemma' is problematic as there are still limitations on a country's independent monetary policy, see Kirshner (n 105) 15-22.

112 The stronger the enforcement, the higher are the sovereignty costs: Brummer (n 22) 260-5. For the relationships between 'legal' power and justifications more generally see Hanoch Dagan, Reconstructing American Legal Realism and Rethinking Private Law Theory (Oxford University Press, 2013) ch 2-4.

${ }^{113}$ For effectiveness as a means to achieve legitimacy see Brummer (n 22) 179-80: 'Theories of output legitimacy thus justify authority not so much on the basis of processes and formal organizational qualities, but on the basis of an institution's accomplishments. In a world of complex decision making, authority can be legitimized by its success in producing the desired outcomes - for example, social welfare gains or global financial stability.' See also Tony Porter, 'The G-7, the Financial Stability Forum, the G-20, and the Politics of International Financial Regulation' (Paper prepared for the International Studies Association Annual Meeting, Los Angeles, California, 15 March 2000) <http://www.g8.utoronto.ca/g20/biblio /porter-isa-2000.pdf $>$. There, while examining the establishment of the FSF, Porter suggests that: '[L]egitimacy is not just something created by the interactions of states nor is it an epiphenomenon of a large-scale compromise between social classes. It is also a characteristic of systems of rules that make them appear to be logical, coherent and fair. Legitimacy can be threatened, then, not just from non-compliance by states or by a strengthening counterhegemony, but also by contradictions and inadequacies in the systems of rules': at 8 . For the link between effectiveness and legitimacy at the global level, see Eyal Benvenisti, "'Coalitions of the Willing" and the Evolution of Informal International Law' in Christian Calliess, Georg Nolte and Peter-Tobias Stoll (eds), Coalitions of the Willing: Avantgarde or Threat? (Carl Heymann, 2007) 1, 26-7: 'Perhaps the most striking feature of the law made by coalitions of the willing is that its claim for legitimacy is not based on the idea of a coherent legal system in which states are equally sovereign and like cases are treated alike. ... Instead, this type of law's claim for legitimacy is based on the perceived justness of the cause pursued by the coalition ... Affected governments and private actors will comply with these laws, not out of [sic] sense of
} 
legitimacy has been relied upon since the emergence of the architecture, and has remained fundamentally untouched despite all crises. ${ }^{114}$ Effectivenessbased legitimacy is compromised due to the expected failure of financial regulation to prevent the next crisis, as argued above. ${ }^{115}$ Yet the argument presented in this article also raises serious concerns regarding the current architecture's democracy-based legitimacy.

I argue that global financial regulation presents us with a unique democratic deficit. Global regulation is, at times, referred to as inherently suffering from a democratic deficit, arising from the lack of democratic participation in its formulation, in contrast to the democratic creation of state law. In particular, two democratic deficits are commonly attributed to global regulation: ${ }^{116}$ 1) administrative deficiencies (often discussed as part of 'global administrative law' or 'GAL'), arising from several causes such as the lack of sufficient judicial review, of transparency and of due process; and 2) differences between a state's ability to influence global decisions and the way these decisions influence that state. Accordingly, procedural solutions (for example, transparency and due process) are offered as a means to correct the first deficit, and cooperation is offered as a means to correct the second deficit. ${ }^{117}$ Such solutions definitely need to be part of the global financial architecture, ${ }^{118}$ but they cannot solve the unique deficit shown in this article, as this deficit is not a matter of procedural legitimacy. I argue that global financial regulation has a

\footnotetext{
legal obligation to do so, but rather out of fear of the adverse effects of non-compliance.' See also Eyal Benvenisti, The Law of Global Governance (Brill, 2014) 207-32.

114 The primary goal of the global architecture is to achieve financial stability. The reforms focus on enhancing the means to achieve this goal, the same goal it pursued before the crisis.

${ }^{115}$ A clarification is in order, as it should not be thought that the offered solution is to go back, and to create financial regulation at the national level. I do not believe this is possible in the face of the existing financial system, and I do not have a strong opinion in regard to how desirable it would be. My comments should be read as a call for change to the current architecture.

${ }^{116}$ For a different approach see, eg, Andrew Moravcsik, 'Is there a "Democratic Deficit" in World Politics? A Framework for Analysis' (2004) 39(2) Government and Opposition 336, 346; Paul E Hubble, 'U.S. Agency Independence and the Global Democracy Deficit' (2013) 88(5) New York University Law Review 1802, 1832-4.

${ }^{117}$ For the fragmentation of international law and its consequences see Benvenisti (n 113) 76-8 and Eyal Benvenisti and George W Downs, 'The Empire's New Clothes: Political Economy and the Fragmentation of International Law' (2007) 60(2) Stanford Law Review 595.

${ }^{118}$ See, eg, Michael S Barr and Geoffrey P Miller, 'Global Administrative Law: The View from Basel' (2006) 17(1) European Journal of International Law 15, for a discussion of GAL and the Basel Committee on Banking Supervision; and James B Kelly, 'A Basis for Governing: Legitimacy, Accountability, and the Value of Uniform Principles for Global Administrative Law' (2017) 86(5) Mississippi Law Journal 995, for a discussion of GAL and the World Trade Organization.
} 
powerful effect on the economic wellbeing of the people, and consequently needs better democratic deliberation and participation than it currently receives. If financial regulation were, as commonly perceived, a technical means for experts to promote the greater good (stability and growth), perhaps only limited democratic participation would be needed. If, however, the situation is closer to that described in this article - with global choices affecting each and every one of us - the lack of deliberation and participation becomes crucial. The immense influence of such deficit is unique to financial regulation.

The democratic deficit that I point to is the result of global financial regulation's intrinsic characteristics (such as its influence on the real economies of states) and its being created at the global level by experts. The deficit has been even greater following the GFC, since the enforcement mechanisms of global financial regulation have become stronger. While this article does not take a position in the ongoing debate about the legitimacy of experts (for example, central banks) within the state, it does argue that, at the global level, their regulations create a deficit simply because they are more distant from (and less accountable to) those who are influenced by their actions than state institutions are.

A comparison could be made to the creation of monetary policy at the global level. ${ }^{119}$ States have given up significant sovereign powers to try and maintain their monetary independence (within the framework of the 'open-economy trilemma'). Given the implications that monetary policy has for the economy, it would seem unreasonable (to many scholars) to create global monetary policy. I argue that, today, regulating the financial system has no fewer implications for the economy.

One could argue that, since global financial regulation is created in a 'soft law' manner and is implemented into states' law, its legitimacy is based on the domestic institutions that adopt it. Once inserted into a domestic legal system, the argument could go, global regulation is transformed and legitimised. Such an argument could be convincing if it were not for global financial regulation's stringent enforcement methods, as described above, and particularly its hardening of soft law. If indeed a state could opt out of certain global standards, but chose to adopt them, this could confer some legitimacy upon those global standards. Yet, as elaborated above, this is not the case for global financial regulation, in particular after the GFC.

\footnotetext{
${ }^{119}$ For the close ties between the two see Frederic S Mishkin, 'Monetary Policy Strategy: Lessons from the Crisis' (Working Paper No 16755, NBER, February 2011) <http://www.nber.org/ papers/w16755>.
} 
As global unelected regulatory bodies determine parts of a state's economy, while preferring certain socio-economic sectors over others, without deliberating upon these implications and without giving those affected a chance to influence the regulation, this deficit emerges. Leaving aside which choice is finally made, the main issue to address is to acknowledge that a choice is being made. If stability could indeed be achieved, a better case for global financial regulation could be made. In such a case, it could be argued that the benefit of global regulation - stability - exceeds its costs - the waiving of financial sovereignty. However if, as this article suggests, stability is not achieved, the costs are far more crucial.

\section{CONCLUDING REMARKS}

This article has provided an examination of the reforms made after the GFC in global financial architecture - structure and content alike. The examination was descriptive, but its results were critically analysed. As stability is the goal that financial regulation tries to achieve, the article has tried to assess whether it is likely to be achieved under the present architecture. Sadly, the findings are not encouraging. It seems that, despite all efforts to harmonise the structure, it remains fragmented; regulation continues to be created by the same bodies as before the crisis. While the FSB is likely to improve coordination between the regulatory bodies, it is unlikely to cause the change needed to avoid past mistakes.

An examination of the contents of global financial regulation after the GFC tends to confirm this conclusion. A comparison of Basel III, as applied to banks, with global regulation for MMFs and repos shows that crucial differences exist at the exact points of risk. The different solutions that are offered to the problem of runs on financial institution may lead to a potential regulatory arbitrage. Such arbitrage could lead to more systemic risk in the financial system and thus counteract efforts to achieve more stability. Moreover, such arbitrage could lead to the growth of the shadow banking sector, along with growing financialisation more generally. These are phenomena whose implications for the real economy are yet to be fully researched.

Consequently, this article argues that the global financial architecture falls short of achieving stability, and at the same time might have questionable effects on the financial system and its connection to the real economy. Its inability to provide effective legal solutions for financial crises jeopardises the legitimacy of the global architecture, which is based on effectiveness. Moreover, its implications for the financial system and the real economy, along with its global nature, lead to a unique democratic deficit. This deficit cannot be healed by the 
use of common tools, such as transparency and due process. It calls for a reorganisation of the global financial architecture.

The good news is that, as argued throughout this article, the architecture and its outcomes are the result of legal design and can therefore be changed to better achieve growth and equality. ${ }^{120}$

${ }^{120}$ See Rawi Abdelal, Capital Rules: The Construction of Global Finance (Harvard University Press, 2007) 218. 